УДК: 65.011 .1

Халіна Вероніка,

кандидат економічних наук, доцент, Харківський національний університет будівництва та архітектури, кафедра економіки, м. Харків, ORCID ID: 0000-0001-6753-6414, e-mail: v.khalina@ukr.net

Васильєва Тетяна, аспірантка,

Харківський національний університет будівництва та архітектури, кафедра економіки, м. Харків, ORCID ID: 0000-0003-0635-7978, e-mail: ha240982vts@gmail.com

https://doi.org/10.29038/2411-4014-2020-01-98-107

\title{
КЛІЕНТООРІЕНТОВАНА СТРАТЕГІЯ РОЗВИТКУ ПІДПРИЕМСТВА: ФОРМУВАННЯ НА ЗАСАДАХ СОЦІАЛЬНОЇ ВІДПОВІДАЛЬНОСТІ У СФЕРІ НАДАННЯ ПОСЛУГ
}

В умовах жорсткої конкуренції на ринку України у сфері надання послуг однією з найважливіших умов виживання та досягнення сталого розвитку компанії в довгостроковій перспективі є розробка та запровадження клієнтоорієнтованої стратегії розвитку. Її реалізація може забезпечити постійне посилення економічної потужності компанії, покращення іміджу та репутації, розширення клієнтської бази, разом 3 цим і підвищення конкурентоспроможності послуг, що надаються. В сучасних економічних умовах однією із найбільш ефективних складових розробки клієнтоорієнтованої стратегії розвитку компанії є соціальна відповідальність. Тому сьогодні, є актуальним запровадження цієї стратегії саме на засадах соціальної відповідальності.

Ключові слова: стратегія, стратегія розвитку, клієнт, клієнтоорієнтованість, соціальна відповідальність.

Халина Вероника, кандидат экономических наук, доцент, Харьковский национальный университет строительства и архитектуры, кафедра экономики, г. Харьков

Васильева Татьяна, аспирантка,

Харьковский национальный университет строительства и архитектуры, кафедра экономики, г. Харьков

\section{КЛИЕНТООРИЕНТИРОВАННАЯ СТРАТЕГИЯ РАЗВИТИЯ КОМПАНИИ: ФОРМИРОВАНИЕ НА ПРИНЦИПАХ СОЦИАЛЬНОЙ ОТВЕТСТВЕННОСТИ В СФЕРЕ ПРЕДОСТАВЛЕНИЯ УСЛУГ}

В условиях жесткой конкуренции на рынке Украины в сфере предоставления услуг одним из важнейших условий выживания и достижения устойчивого развития компании в долгосрочной перспективе является разработка и внедрение клиентоориентированной стратегии развития. Ее реализация может обеспечить постоянное усиление экономической мощи компании, улучшение имиджа и репутации, расширение клиентской базы, вместе с этим и повышение конкурентоспособности услуг. В современных экономических условиях одной из наиболее эффективных составляющих клиентоориентированной стратегии развития компании является социальная ответственность. Поэтому, в настоящее время актуальным и целесообразным будет в данную стратегию, в качестве фундамента, заложить именно принципы социальной ответственности. 
Ключевые слова: стратегия, стратегия развития, клиент, клиентоориентированность, социальная ответственность.

\author{
Khalina Veronika, \\ Candidate of Economic Sciences, associate professor, \\ Kharkiv National University of Civil Engineering and Architecture, \\ Department of Economics \\ Kharkiv \\ Vasil'eva Tatyana, \\ postgraduate student, \\ Kharkiv National University of Civil Engineering and Architecture, \\ Department of Economics, \\ Kharkiv
}

\title{
CLIENT-ORIENTED ENTERPRISE DEVELOPMENT STRATEGY: FORMING SOCIAL RESPONSIBILITY FOR SERVICES
}

Introduction. In the conditions of fierce competition on the Ukrainian market in the sphere of providing services, one of the most important conditions for survival and achievement of sustainable development of the company in the long term is the development and implementation of a client-oriented development strategy. Its implementation can provide constant strengthening of the economic power of the company, improvement of image and reputation, expansion of the client base, and at the same time increase the competitiveness of the provided services. It is safe to say that the client today is a key factor in the success of the organization. In today's economic environment, social responsibility is one of the most effective components of developing a customer-centric strategy for company development. Therefore, today it is relevant to implement this strategy on the basis of social responsibility. We are all users of different services and we can confidently say who we will prefer when choosing a service provider, namely: who will be responsible for their actions, behavior, decisions; to those who are transparent in the market; to who will solve your problem if necessary; ethical behavior; to one who acts according to the rules of laws and standards; to those who care about customer reliability, safety and health. The purpose of the article is to formulate the goals and actions of the client-oriented approach, to develop the client-oriented strategy on the principles of social responsibility. Results. The article identifies and analyzes the evolutionary stages development of client-oriented approach and approaches to interpretation of the concept, the author offered his vision for definition. A client-centered approach to classifying strategies by stage of economic development was proposed, and an author-based client-centered strategy was formed. Conclusions. Creating a client-oriented development strategy is a rather long step, which requires focusing on the main value of the company - clients, without whom it is impossible to achieve sustainable development, to get leading positions in the market of services in the conditions of turbulent state of the economic system.

Key words: strategy, development strategy, customer, customer orientation, social responsibility.

Постановка проблеми та їі визначення. Задоволеність клієнтів та ефективність бізнесу досягаються за умови реалізації завчасно спланованої програми, яка спрямована на пошук потенційних споживачів, розробку продуктів (товарів та послуг) компанії, напрацювання каналів збуту та ефективну їх реалізацію з урахуванням об'єктивних даних щодо попиту цільових груп, основою якої $\epsilon$ застосування напрацьованих алгоритмів роботи та встановлення стійких i взаємовигідних зв'язків зі споживачами, що відображають фактичне задоволення інтересів на усіх етапах взаємодії як внутрішніх так і зовнішніх клієнтів компанії [1].

Ключовим фактором успіху організації $є$ споживачі/клієнти, які забезпечують тим самим створення зовнішньої конкурентної переваги. Для успішного досягнення стратегічних цілей споживач/клієнт повинен бути інтегрований в центр процесу планування діяльності організації. Це завдання вирішується за допомогою комплексу заходів стратегічного маркетингу, кінцевою метою якого є розробка клієнтоорієнтованої стратегії розвитку [2].

Необхідність та актуальність запровадження клієнтоорієнтованої стратегії виникають 3 умов сучасного ринку надання послуг, а саме:

- надлишок схожих пропозицій; 
- жорстка конкурента боротьба;

- постійний або знижуючий запит на послугу;

- особливі вимоги користувачів послуг до якості;

- зростаючі запити користувачів до кваліфікації персоналу;

- наявність на ринку послуг специфічних пропозицій;

- постійне удосконалення ринку послуг, що надаються;

- соціально - відповідальна поведінка компанії, що надає послуги.

Соціально - відповідальна поведінка компанії у сучасних умовах є фундаментом для створення клиєнтоорієнтованої компанії. Ми всі $є$ користувачами різних послуг і з впевненістю можемо сказати, кому ми віддамо перевагу при виборі надавача послуг, а саме: тому, хто буде нести відповідальність за свої дії, вчинки, рішення; тому, хто прозоро працює на ринку; тому, хто вирішить твою проблему у разі необхідності; тому, хто дотримується етичної поведінки; тому, хто діє за нормами законів та стандартів; тому, хто піклується про надійність, безпеку та здоров'я клієнта. Доречним є підхід Р. Дала, згідно якому «сьогодні абсурдно розглядати корпорації просто як підприємства, які засновані для єдиної мети отримання прибутку. Ми, громадяни, даємо їм спеціальні права, владу і привілеї, захист і переваги на основі розуміння, що їх діяльність буде ... приносити нам користь ... Кожна корпорація повинна розглядатися як соціальне підприємство, чиє існування і рішення можуть бути виправдані, тільки якщо вони служать громадській або соціальній меті» $[3,4]$.

Аналіз останніх досліджень і публікацій. Дослідження проблем, пов'язаних з формуванням та вибором стратегії розвитку підприємства, займаються багато вітчизняних та зарубіжних вчених, зокрема: І. Ансоффа, О. Виханського, О. Градова, В. Гриньової, М. Портера, О. Пушкаря, А. Стрікленда, А. Томпсона, В. Забродського, А. Зуба, Т. Сааті, В. Василенко, І. Ігнатьєвої, 3. Шершньової, Т. Ткаченко, Б. Мізюка, В. Мартиненка, А. Мазаракі, Л. Мельника, Ю. Дерев’янка, В. Пономаренка та багатьох інших.

Дослідженням клієнтоорієнтованості компаній через ії актуальність сьогодні займаються багато як вітчизняних, так і зарубіжних експертів: В. В. Бусаркина, Дж. К. Нарвер, С.Ф. Слейтер , В. Лошков , Б. Рыжковский, К. Харский И., Воржакова Ю.П., Новіков А., Кулинич А., И.А. Никонова, Р.Н. Шамгунов та ін.

Аспектами соціальної відповідальності бізнесу займалися такі зарубіжні та вітчизняні вчені як: Г. Саприкіна, С. Харічков, А. Бутенко, А. Зінченко, Н. Діденко, В. Гетьман, Р. Дала, А. Керолл, М. Фрідман, Г. Боуен.

Мета й завдання статті. Формування цілей та дій клієнтоорієнтованого підходу, розробка клієнтоорієнтованої стратегії на засадах соціальної відповідальності.

Виклад основного матеріалу та обгрунтування отриманих результатів дослідження. В часи орієнтації на виробництво, коли головним було створити товар та розширити виробництво, рівень уваги до клієнтів був достатньо низьким. Споживачам було складно знайти незалежну інформацію про товари/послуги, вони не мали можливості висказати своє негативне ставлення до організації, оперативно зв'язатися, щоб вирішити конкретні питання [7]. В ті часи, процес продажу носив приблизно однаковий характер, широкого вибору не було. Але прийшла нова реальність та діють інші правила.

Скористаємось методологією, що описує стадії розвитку організації, яка була розроблена одним з ведучих світових експертів І. Адізесом, і на ії засадах, визначимо стадії еволюційного розвитку клієнтоорієнтованого підходу (рис.1).

На стадії доглядання увага приділяється масштабному виробництву. В пріоритеті було залучення нових клієнтів та розвиток вже існуючих продуктів, але рівень уваги до потреб споживачів дуже низький.

На стадії дитинства приходить розуміння того, що чим більше клієнтів, тим вище прибуток компанії. Підприємства прикладають зусилля для переконання клієнтів обрати саме їх товар/послугу. Формується клієнтоорієнтовна стратегія розвитку підприємства.

Наступна стадія вже характеризується сегментуванням споживачів та ідентифікуванням їх потреб. У роботі з клієнтами вирішуються два завдання: утримання прибуткових клієнтів та вживання заходів щодо збільшення кількості їх покупок в даній компанії. 
На стадії юності підвищується інноваційна складова виробничого потенціалу підприємства за рахунок системного використання взаємин з клієнтами. Застосування інтернет та CRM технологій для формування та підтримування лояльності клієнтів.

На стадії розквіту клієнт стоїть у центрі процесу и розглядається як ресурс та джерело можливостей для росту та розвитку компанії [11].

За методологією Адізеса ще виділяються стадії стабільності, аристократизму, ранньої бюрократизації, бюрократизації та смерті. В нашому випадку еволюція клієнтоорієнтованого підходу ми зупинимося на стадії розквіту, коли організації усвідомлюють цінність клієнта і відносять його до центру всієї філософії будування бізнес-процесів.

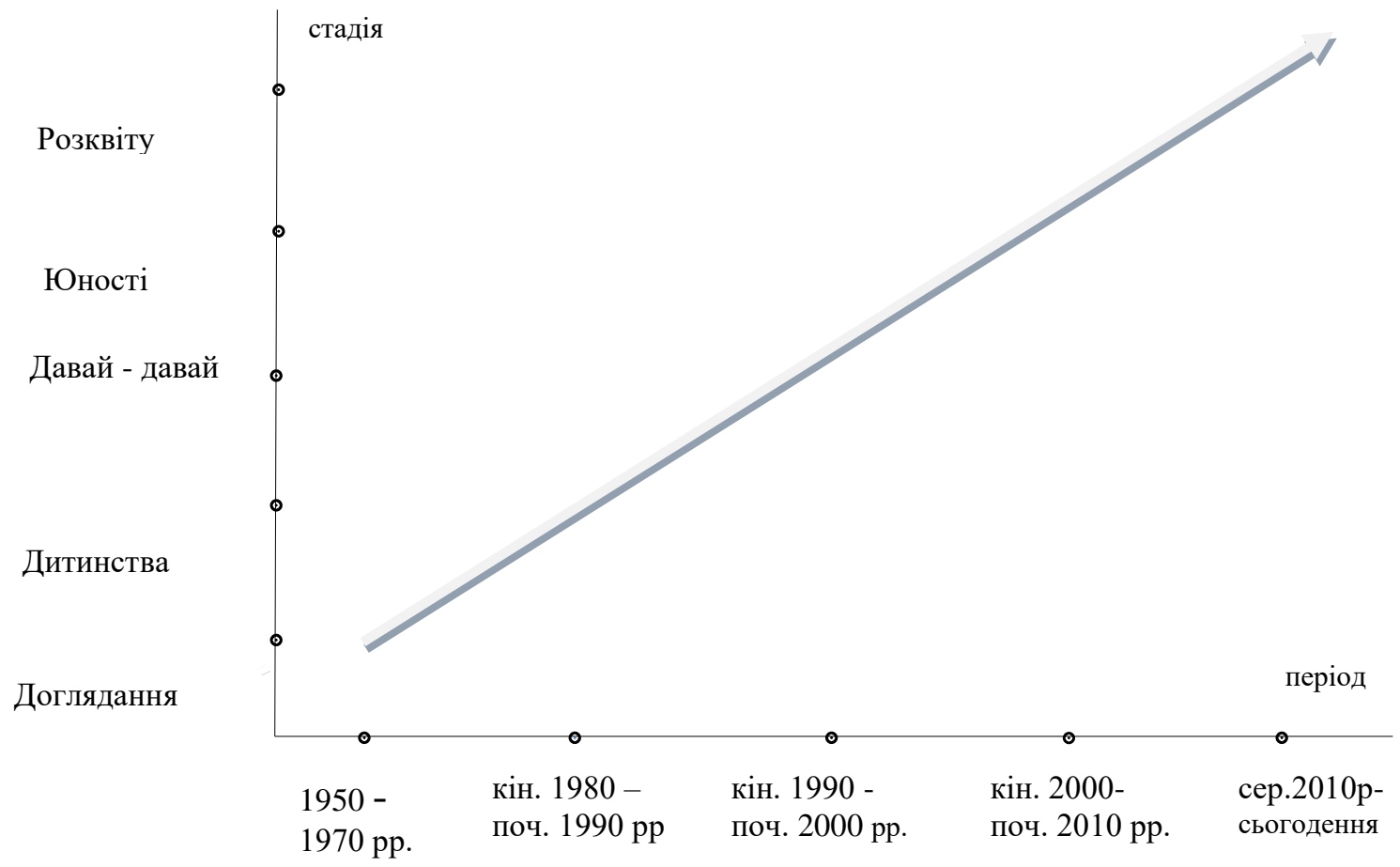

Рис. 1. Еволюиія клієнтоорієнтованого підходу за стадіями розвитку

Джерело: укладено на основі $[8,9]$.

Також ми можемо спостерігати, як зарубіжні та вітчизняні вчені підходять до визначення клієнтоорієнтованого підходу (КП) у різні стадії його становлення (табл.1).

Таблиия 1

Підходи до визначення кліснтооріснтованості за стадіями розвитку

\begin{tabular}{|c|c|c|}
\hline Стадія КП & Автор & Визначення \\
\hline \multirow[b]{2}{*}{ Доглядання } & Дракер П., 1954 & $\begin{array}{l}\text { Сдина реальна мета бізнесу - створення клієнтів, тому у } \\
\text { компанії є тільки дві основні функції: маркетинг та } \\
\text { інновації }\end{array}$ \\
\hline & Левітт Т., 1960 & $\begin{array}{l}\text { Щоб отримати велику кількість клієнтів, уся компанія } \\
\text { повинна розглядатися як організм по створенню клієнтів і } \\
\text { їх задоволенню. Компанія повинна мислити себе не як } \\
\text { виробник послуг та продуктів, а як того, хто забезпечує } \\
\text { реалізацію цінностей, привабливих для споживача }\end{array}$ \\
\hline \multirow[b]{2}{*}{ Дитинства } & Сахе, Вейтз, 1982 & 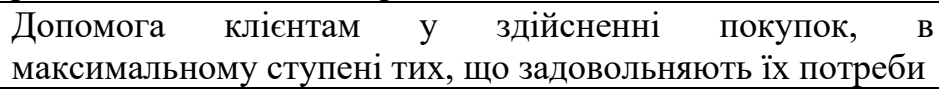 \\
\hline & $\begin{array}{l}\text { Петерс, Ватерман, } \\
1982\end{array}$ & $\begin{array}{l}\text { Підвищена увага співробітників до сервісу та якості, } \\
\text { кастомізація продукту, активний збір та аналіз інформації } \\
\text { про потреби клієнтів }\end{array}$ \\
\hline
\end{tabular}




\begin{tabular}{|c|c|c|}
\hline \multirow[b]{2}{*}{ Давай - давай } & $\begin{array}{c}\text { Кохлі, Яворський, } \\
1990\end{array}$ & $\begin{array}{l}\text { Збір і поширення інформації про потреби клієнтів, } \\
\text { адаптація продуктів, послуг і процесів відповідно до } \\
\text { отриманих даних }\end{array}$ \\
\hline & $\begin{array}{l}\text { Р. Дешпндэ, Дж.У. } \\
\text { Фарлей, Ф.Е. } \\
\text { Вебстер, } 1993\end{array}$ & $\begin{array}{l}\text { Частина корпоративної культури, набір переконань, що } \\
\text { ставить інтереси клієнта на перше місце перед інтересами } \\
\text { менеджерів, акціонерів, працівників. Фокус не тільки на } \\
\text { розумінні потреб існуючих і потенційних клієнтів, а також } \\
\text { на розумінні їх цінностей і переконань }\end{array}$ \\
\hline \multirow{3}{*}{ Юності } & $\begin{array}{l}\text { Б. Рыжковский, } \\
2005\end{array}$ & $\begin{array}{l}\text { Інструмент управління взаємовідносинами } 3 \text { клієнтами, } \\
\text { націлений на отримання стійкого прибутку в } \\
\text { довгостроковому періоді що базується на трьох критеріях: } \\
\text { ключова компетенція, цільові клієнти і рівність позицій }\end{array}$ \\
\hline & К. Харский, 2007 & $\begin{array}{l}\text { Клієнтоорієнтованість - це стратегія максимізації } \\
\text { прибутку компанії за рахунок створення умов, за яких } \\
\text { клієнт бажає укласти угоду, потім другу і всі наступні. Це } \\
\text { не те, що ви думаєте зробити для клієнта, це те, що клієнт } \\
\text { думає про вас; це не те, що компанія робить для свого } \\
\text { клієнта, це не те, що вона збирається зробити, це не те, що } \\
\text { вона хоче зробити, це не те, що вона може зробити при } \\
\text { необхідності. Це оцінка клієнтом видимої частини } \\
\text { діяльності компанії }\end{array}$ \\
\hline & $\begin{array}{c}\text { В.В. Бусаркина, } \\
2007\end{array}$ & $\begin{array}{l}\text { Клієнтоорієнтованість - інструмент партнерської } \\
\text { взаємодії організації та клієнта по задоволенню його } \\
\text { потреб, націлений на отримання стійкого прибутку в } \\
\text { довгостроковому періоді, за допомогою відповідних } \\
\text { ключових компетенцій організації }\end{array}$ \\
\hline \multirow{3}{*}{ Розквіту } & И. Манн, 2011 & $\begin{array}{l}\text { Ініціація позитивних емоцій у потенційних і існуючих } \\
\text { клієнтів, що веде до вибору товарів і послуг вашої } \\
\text { компанії серед безлічі конкурентів, до повторних покупок } \\
\text { і отримання нових клієнтів за рахунок рекомендацій } \\
\text { існуючих клієнтів }\end{array}$ \\
\hline & Л. Стрій, 2011 & $\begin{array}{l}\text { Маркетинг відносин - це філософія } \\
\text { спрямована наретингу, } \\
\text { взаємовигідних відносин співробітництва } 3 \text { усіма } \\
\text { учасниками процесу планування, виробництва і розподілу } \\
\text { товарів, послуг та інформації з метою забезпечення } \\
\text { тривалого процвітання підприємства, підтримки i } \\
\text { поліпшення благополуччя його партнерів, споживачів i } \\
\text { суспільства в цілому }\end{array}$ \\
\hline & А. Кулинич, 2012 & $\begin{array}{l}\text { Клієнтоорієнтованість це коктейль з бажання зрозуміти } \\
\text { клієнта, чесності і формування очікувань, високій } \\
\text { задоволеності обслуговування фронт-офиса внутрішнім } \\
\text { клієнтом і щоденною боротьбою за економічну } \\
\text { ефективність. Клієнтоорієнтованість це часто не сервіс, } \\
\text { клієнтоорієнтованість це розуміти і робити те, що важливо } \\
\text { для клієнта }\end{array}$ \\
\hline
\end{tabular}

Джерело: укладено на основі [12, 13, 14, 15, 16, 17, 18, 19, 20, 21, 22, 23]

Аналізуючи таблицю, можна сказати, що на ранніх стадіях розвитку клієнтоорієнтованого підходу його дослідженнями займалися тільки зарубіжні науковці, тільки на стадії юності почали приділяти увагу і ретельно вивчати й вітчизняні. За наведеними багатогранними дефініціями, клієнтоорієнтованість - це мета бізнесу, стратегія, реалізація цінностей, допомога та увага, частина корпоративної культури, інструмент управління взаємовідносинами, ініціація позитивних емоцій. Підходів до визначення клієнтоорієнтованого підходу дуже багато, кожний науковець має свою думку й тлумачення. 
Підбиваючи підсумки, автором запропоновано свій підхід до визначення клієнтоорієнтованості. Отже, клієнтоорієнтований підхід - це робота над собою: повірити в себе, удосконалювати свої навички, з ентузіазмом і професіоналізмом ставитися до справи, зробити клієнта вищою цінністю організації; створити атмосферу затишку та комфорту, незабутні враження, відчуття турботи та довіри від співпраці.

За останні десятиріччя поведінка клієнта дуже змінилась. Зараз споживачі очікують персоналізованої технологічної поведінки, постійного накопичення інформації. Бажають, щоб їх досід був простим, миттєвим та інтуїтивним [10]. Вони стали більш свідомими і прагнуть до високих цілей у своїх рішеннях. Клієнти розраховують на простий контакт з організацією, а також на поважну реакцію, якщо виникають зауваження, хочуть відчувати, що про них піклуються та турбуються.

Виходячи з вищенаведеного, швидкі зміни розвитку компаній, що пов'язані з появою нових технологій, глобалізацією діяльності, посиленням конкуренції на ринках, обумовлюють необхідність ïх пристосування до змін оточуючого середовища. Тому вибір, розробка та впровадження стратегії $\epsilon$ основним пріоритетом сталого розвитку. Існує досить багато класифікацій стратегії підприємств, що відрізняються набором та кількістю класифікаційних ознак. Варто зазначити, що майже всі автори виділяють так звані базові стратегії, однак у деяких джерелах вони можуть бути визначені за класифікацією відповідно до життєвого циклу підприємства - стратегії зростання, стратегії стабілізації та стратегії скорочення [5].

Скористаємось знову концепцією Адізеса та запропонуємо клієнтоорієнтований підхід на засадах соціальної відповідальності стратегій економічного розвитку організації, використовуючи п'ять ключових компонентів клієнтоорієнтованості (рис.2). Для цього ми увагу зупинили на стадії розквіту, коли організація займається плануванням та діє згідно цих планів, орієнтована на ефективний результат в короткостроковій і довгостроковій перспективі та максимальне задоволення потреб клієнтів; на стадії стабільності, де вже зменшується гнучкість системи, відбувається скорочення інновацій, що негативно впливає на результат організації та взаємовідносини 3 клієнтами; та стадії ранньої бюрократизації, коли організація віддає перевагу заходам, які дозволяють досягнути тільки короткострокових результатів, не звертаючи уваги на цінність споживачів.

Процес розробки клієнтоорієнтованої стратегії є досить тривалим, щоб отримати ефективний результат від іiі реалізації, необхідне залучення не тільки керівництва, але й кожного працівника компанії. Кожен повинен усвідомити свою відповідальність та свій внесок у підготовку та надання кінцевого результату (послуги) в єдиному ланцюжку створення цінності для клієнта.

Автором запропонована розробка клієнтоорієнтованої стратегії (КС) для компанії, що спеціалізується на ринку послуг (рис. 3).

На першому етапі сформулювати бачення, ключові цінності та переконання організації. Визначити стратегічні цілі, а саме, який ефект компанія бажає отримати від нової клієнтоорієнтованої стратегії.

На другому етапі запропонованої стратегії необхідно провести комплексний аудит стану існуючого клієнтоорієнтованого підходу компанії, стандартів, інструкцій, що регламентують діяльність працівників з обслуговування клієнтів, організаційної структури. Провести діагностику компанії, виявити слабкі та сильні сторони, зробити SWOT-аналіз. Зібрати та обробити інформацію аналогічних компаній, виявити їх конкурентні переваги. Проаналізувати потребу у ресурсах, необхідних для досягнення стратегічних цілей.

Наступним кроком, сформулювати концепцію клієнтоорієнтованої стратегії. Розробити та затвердити стандарти якості обслуговування клієнтів організації на основі вже затверджених Міністерствами, нормативні документи, що регламентують систему взаємовідносин $з$ клієнтами. Запровадити нові функціональні обов'язки, підрозділи, якщо виникає потреба, то провести зміни в організаційній структурі. Актуалізувати структуру сервісів та процесів. Процесно-сервісний підхід базується на глибокому розумінні короткострокових і довгострокових потреб клієнта, трендів ринку i дозволяє зайняти проактивну позицію по відношенню до замовника послуги. Запровадити моніторинг якості послуг, рівня задоволеності клієнтів, створення CRM-системи; формування та супровід каталогу послуг, забезпечити його доступність для клієнту, наявність чітко зафіксованої 
інформації щодо повного змісту послуг; оптимізація бізнес - процесів клієнтоорієнтованості, 3 метою забезпеченості оперативного реагування на потреби клієнтів.

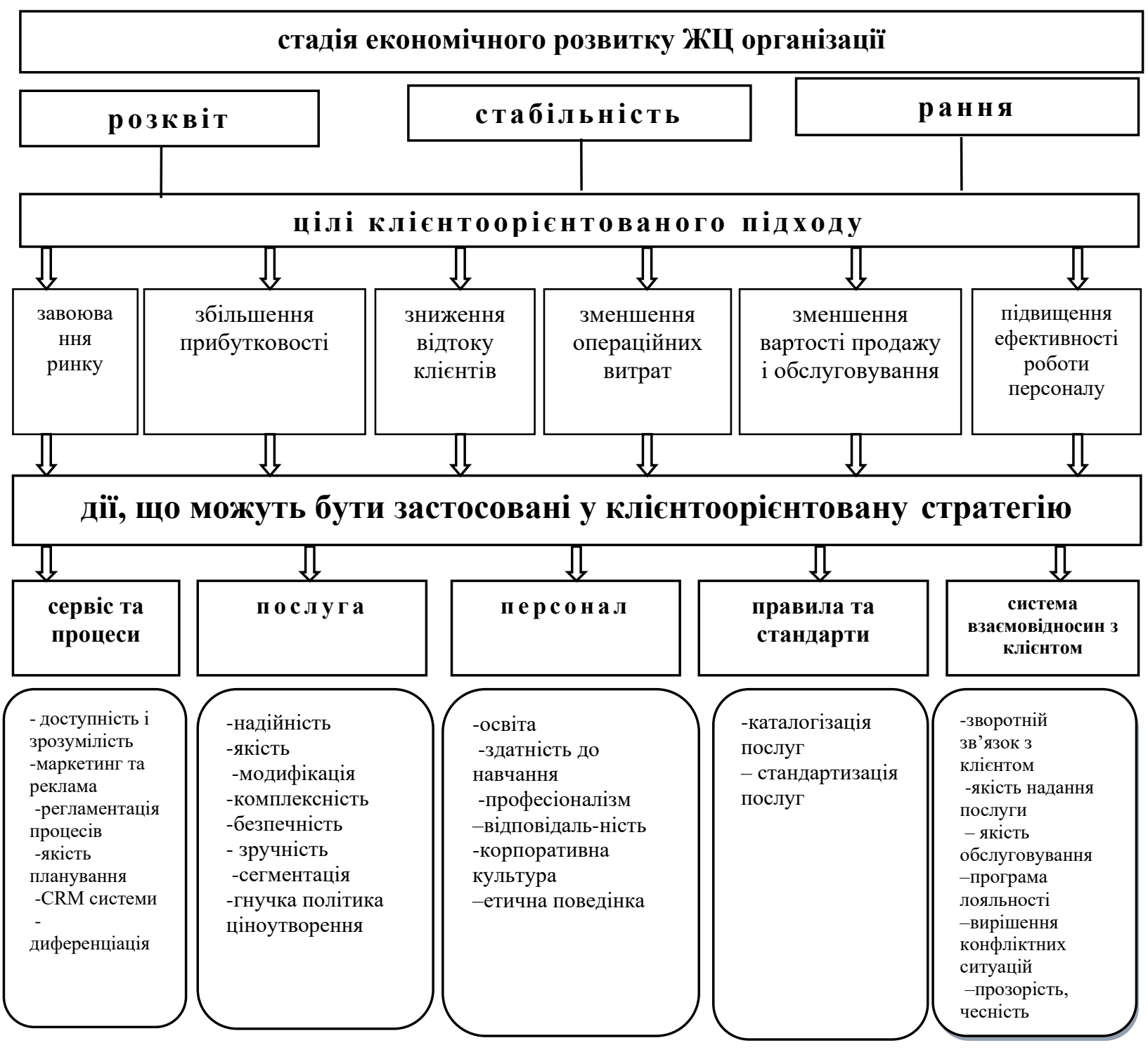

Рис. 2. Клієнтоорієнтований підхід в класифікаиії стратегій за стадією економічного розвитку Джерело: укладено на основі [6,8]

Окремо виділити процес фахової підготовки персоналу. Щоб клієнт залишився задоволеним і в подальшому застосував ефект «сарафанного радіо», компанія повинна прагнути досягти бездоганного сервісу. На цьому етапі необхідно запровадити систему навчання принципам і технологіям ефективного маркетингу і просування послуг, вмінню і навичкам роботи з клієнтами, удосконалювати систему мотивації персоналу і ключових показників діяльності, заохочувати i надавати підтримку в розробці і реалізації відповідних ініціатив. Відповідально підходити до відбору працівників, робити акцент на освіту, професіоналізм, відповідальність, норми етичної поведінки. Запровадити постійний контроль за якістю виконання своїх професійних обов'язків, долучивши «таємного покупця» послуг. Разом 3 цим, сформувати систему ідеальних відносин 3 клієнтами, застосовуючи принципи соціальної відповідальності. Для цього необхідно запровадити достатній рівень інформованості клієнтів про компанію та її послуги. До інформації ставити такі вимоги: вона повинна бути достовірною, цінною, повною, своєчасною, зрозумілою, доступною та стислою. Сервіс має бути якісним, доступним, зручним, надійним, безпечним. Створити або удосконалити канали 
зворотного зв'язку: телефонна лінія, вікно споживача, обмін інформацією у просторах інтернету. Розробити програми лояльності для клієнтів, а також гнучку політику ціноутворення для пільгової категорії населення, що користується послугами.

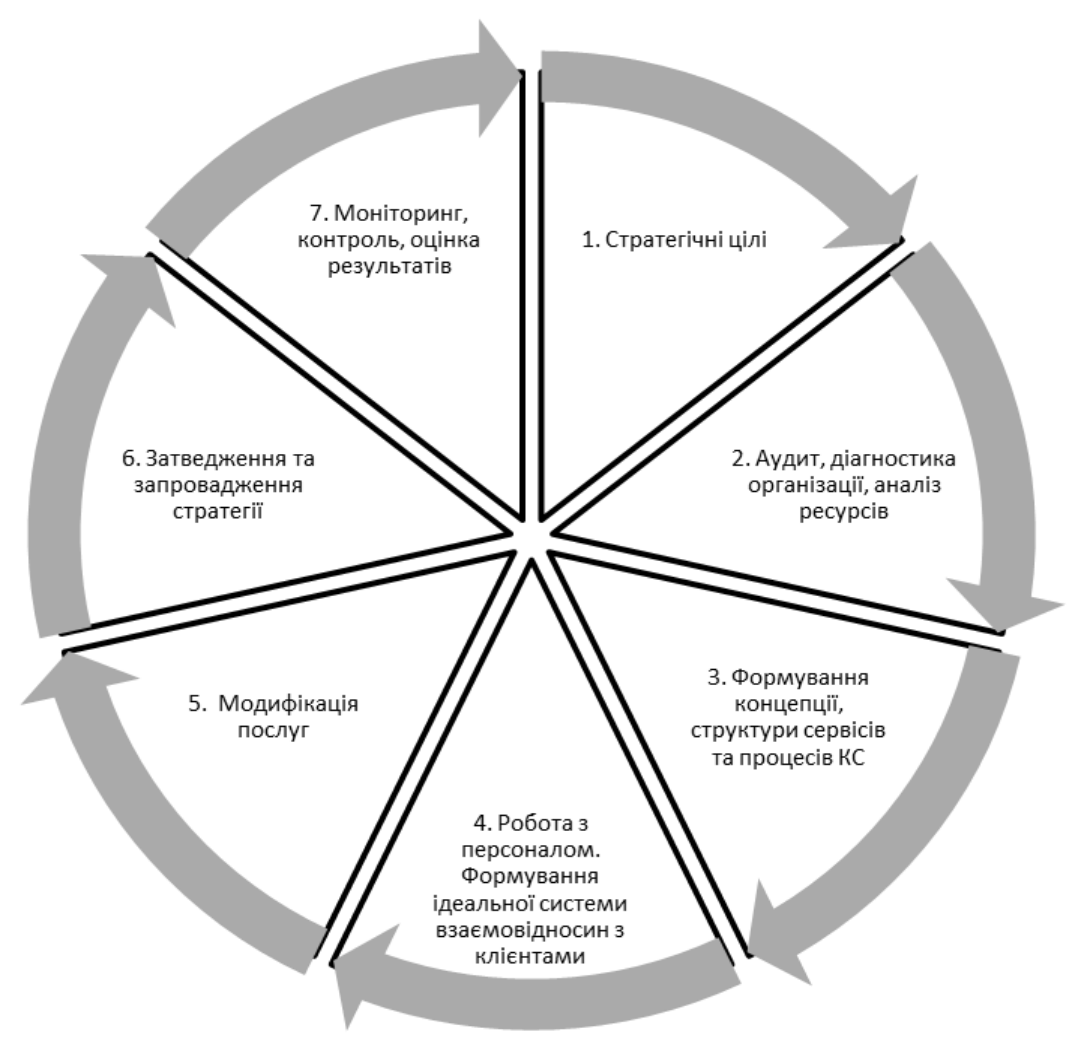

Рис. 3. Формування клієнтоорієнтованої стратегії

Джерело: розроблено автором

Bci перетворення націлені на результативне та ефективне задоволення потреб клієнта, тому, обов'язково необхідно приділити особливу увагу послугам, які пропонуються в компанії. Модифікувати їх, згідно потреб клієнтів, усунути наявні недоліки, оновити, використавши сучасні технології. Зробити акцент на якості, надійності, зручності, комплексності, безпечності, доступності для будь якої категорії населення.

На шостому етапі презентуємо розроблену клієнтоорієнтовану стратегію керівникам відділів,

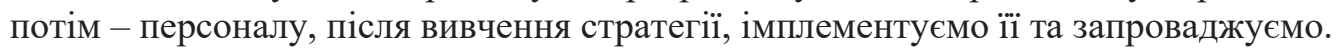

На начальних етапах реалізації щотижня необхідно робити звіт щодо іiі відповідності очікуванням клієнтів, змінам оточуючого середовища, відповідності до поставлених стратегічних завдань та цілей організації. Згодом аудит стратегії рекомендовано проводити кожні пів року, враховуючи постійні зміни у зовнішніх та внутрішніх факторах. Разом 3 цим продовжувати постійний пошук шляхів та засобів покращення якості послуг.

Висновки і перспективи подальших досліджень. Підбиваючи підсумки 3 вищенаведеного, автором запропоновано своє бачення визначення клієнтоорієнтованої стратегії розвитку підприємства на засадах соціальної відповідальності, а саме - це результат чіткого плану дій, спрямованого на вирішення довгострокових завдань по покращенню бізнес-процесів, безперервному формуванню портфелю клієнтів та удосконаленню системи взаємовідносин 3 клієнтами, а саме: відповідальність за дії та вчинки, орієнтація на прозорість, надійність, безпечність; стабільність росту якості послуг та обслуговування, дотримання етичної поведінки та норм стандартів та законів.

Створення клієнтоорієнтованої стратегії розвитку досить тривалий етап, який потребує зосередження на головній цінності компанії - клієнтах, без яких неможливого досягти сталого розвитку, отримати лідируючі позиції на ринку послуг в умовах турбулентного стану економічної 
системи. Завоювати довіру клієнта - один з критеріїв успішності бізнесу, бо якщо з першого разу цього не сталося, то ймовірність другого шансу дуже мала. Тому, соціально - відповідальна поведінка компанії дає змогу клієнтам відчути, як про них турбуються та діють в їх інтересах, що дає можливість повертатися знову. 3 впевненістю можна сказати, що подальші дослідження по цій темі $\epsilon$ вкрай важливими для компаній, метою яких є довгострокова перспектива на сталий розвиток, утримання лідируючих позицій на ринку послуг, враховуючи швидкі зміни оточуючого середовища.

\section{Джерела та література}

1. Рябоконь Н. П., Мартінович В. Г. Індикатори клієнтоорієнтованого підходу. Науковий вісник Херсонського державного університету. Сер. : Економічні науки. 2016. Вип. 21(2). С. 104-107 URL: http://nbuv.gov.ua/UJRN/Nvkhdu_en_2016_21(2)_27

2. Маркетинг. Підручник і практикум: підручник для бакалаврів / за редакцією Л. А. Данченок. Москва: Юрайт, 2015. 486 с.

3. Черкашин П. Чи готові Ви до війни за клієнта? Стратегія управління взаємовідносинами з клієнтами (CRM). M .: TOB «IHTYIT.py», 2004. 384 c.

4. Dahl R.A. A Prelude to Corporate Reform. Business and Society Review. Spring, № 1, 1972. c. 17-23

5. Трофіменко О.О., Войтко С.В. Функціонування, стратегічний розвиток и регулювання відновлюваної енергетики: монографія. К.: Альфа Реклама, 2014. 178 с.

6. Зинкевич А. Секреты клиенториентированности: руководство по приобретению преданных клиентов. E-reading.club, 2014. URL: http://www.e-reading.club/bookreader.php/1024256/Zinkevich_-_Secrets_client.pdf.

7. 5 современных принципов продаж: что изменилось за 30 лет? LPGENERATOR, 2016. URL: https://lpgenerator.ru/blog/2016/01/12/5-sovremennyh-principov-prodazh-chto-izmenilos-za-30-let/

8. Адизес И. Управление жизненным циклом корпорации. Пер. з англ. под науч. ред. А.Г. Сеферяна. СПб.: Питер, 2008. 384 с. c. 34-48.

9. Ковальчук С. Розвиток клієнтоорієнтованості засобами краудсорсингу. Маркетинг в Україні. 2015. № 5.

10. Соломон М. Високі технології роботи з клієнтами. Як перетворити випадкового споживача в щирого прихильника. Вид.: Манн, Іванов, Фербер, 2013. 256 с.

11. Толстобров Д.А., Толстоброва Н.А. Влияние клиентоориентированной политики предприятия на организацию производственного процесса. Фундаментальные исследования. 2014. № 12(3). с. 606-611.

12. Drucker P. The Practice of Management. Harper: New York, NY. 1954.

13. Хлопотіна М. Фокус на клієнта. Персонал. 2018. № 1. URL: http://iron.metalloinvest.com/page/clientfocus $/ \% 20 \% \mathrm{D} 1 \% 84 \% \mathrm{D} 0 \% \mathrm{BE} \% \mathrm{D} 1 \% 82 \% \mathrm{D} 0 \% \mathrm{BE} \% 20 \% \mathrm{D} 0 \% \mathrm{~B} 2 \% 20 \% \mathrm{D} 1 \% 82 \% \mathrm{D} 0 \% \mathrm{~B} 5 \% \mathrm{D} 0 \% \mathrm{BB}$

14. Saxe R., Weitz B. The SOCO scale: A measure of the customer orientation of salespeople. Journal of Marketing Research 1982. 19 (3). c. 343-351.

15. Peters T., Waterman R. In Search of Excellence. Warner: New York, NY. 1982.

16. Kohli A., Jaworski B. Market orientation: The construct, research propositions, and managerial implications. Journal of Marketing 1990. 54 (2). c. 1-18

17. Deshpande R., Farley J. U., and Webster F. E. Corporate culture, customer orientation and innovativeness in Japanese firms: a quadrant analysis. Journal of Marketing 1993. 57 (1). c. 23-37

18. Рыжковский Б. Когда клиент голосует деньгами? Управление компанией. 2005. № 7. URL: http://www.advertology.ru/ article27313.htm

19. Харский К. Клиентоориентированность как она есть. Управление сбытом. 2007. № 3. С. 34.

20. Бусаркина В.В. Понятие клиентоориентированности предприятия и проблемы ее оценки. Проблемы современной экономики. 2007. № 4 (24). URL: http://www.m-economy.ru/ art.php?nArtId=1660

21. Манн И. Клиентоориентированность: что делать, как делать, взять и сделать. Стратегии. 2013. URL: http://pharma.net.ua/publications/articles/44566-klientoorientirovannost-chto-delat-kak-delat-vzyat-i-sdelat

22. Стрій Л.О. Маркетингове управління на рубежі XXI століття: системне дослідження: монографія. Одеса: Астропринт, 2011. 304 с.

23. Кулинич А. Клиентоориентированность: вся правда от практичного теоретика. Цифровые стратегии. URL: https://kulinich.ru/pravda-o-klientoorientirovannosti/

\section{References}

1. Rjabokonj, N. P., Martinovych, V. Gh. (2016). Indykatory klijentoorijentovanogho pidkhodu [Indicators of customer-oriented approach]. Naukovyj visnyk Khersonsjkogho derzhavnogho universytetu. Serija: Ekonomichni, 21(2), 104-107, available at: http://nbuv.gov.ua/UJRN/Nvkhdu_en_2016_21(2)_27 [in Ukrainian]. 
2. Danchenok, L. A. (2015). Marketyngh. Pidruchnyk i praktykum: pidruchnyk dlja bakalavriv [Marketing. Tutorial and practicum: a tutorial for bachelors], Bakalavr. Bazovyj kurs, Moskva, Jurajt, 486 [in Russian].

3. Cherkashyn, P. (2004). Chy ghotovi Vy do vijny za klijenta? Strateghija upravlinnja vzajemovidnosynamy z klijentamy [Are you ready for the war for the client? Customer relationship management strategy]. Moskva, TOV «INTUIT.ru», 384 [in Russian].

4. Dahl, R.A. (1972) A Prelude to Corporate Reform, Business and Society Review, № 1, 17-23 [in English].

5. Trofimenko, O.O., Vojtko, S.V. (2014). Funkcionuvannja, strateghichnyj rozvytok y reghuljuvannja vidnovljuvanoji energhetyky: monoghrafija [Functioning, strategic development and regulation of renewable energy: a monograph], Kyjiv, Aljfa Reklama, 178 [in Ukrainian].

6. Zinkevich, A. (2014). Sekrety klientorientirovannosti: rukovodstvo po priobreteniju predannyh klientov [Client Secrets Secrets: A Guide to Acquiring Loyalty Clients], E-reading.club, available at: http://www.ereading.club/bookreader.php/1024256/Zinkevich - Secrets client.pdf [in Russian].

7. LPGENERATOR (2016). 5 sovremennyh principov prodazh: chto izmenilos' za 30 let? [5 modern sales principles: what has changed in 30 years?], available at: https://lpgenerator.ru/blog/2016/01/12/5-sovremennyhprincipov-prodazh-chto-izmenilos-za-30-let/ [in Russian].

8. Adizes, I. (2008). Upravlenie zhiznennym ciklom korporacii [Corporate Lifecycle Management], Per. z angl. pod nauch. red. A.G. Seferjana, SPb, Piter, 384 [in Russian].

9. Kovaljchuk, S. (2015). Rozvytok klijentoorijentovanosti zasobamy kraudsorsynghu [Developing client orientation through crowdsourcing], Marketyngh v Ukrajini, № 5, 34-48 [in Ukrainian].

10. Solomon, M. (2013). Vysoki tekhnologhiji roboty z klijentamy. Jak peretvoryty vypadkovogho spozhyvacha $\mathrm{v}$ shhyrogho prykhyljnyka [High technology of work with clients. How to turn a casual consumer into a genuine fan], Vyd.: Mann, Ivanov, Ferber, 256 [in Ukrainian].

11. Tolstobrov, D.A., Tolstobrova N.A. (2014). Vlijanie klientoorientirovannoj politiki predprijatija na organizaciju proizvodstvennogo processa [The impact of customer-oriented enterprise policies on the organization of the production process], Fundamental'nye issledovanija, № 12(3), 606-611 [in Russian].

12. Drucker, P. (1954). The Practice of Management. Harper, New York [in English].

13. Hlopotina, M. (2018). Fokus na klienta [Customer focus], Personal, № 1, available at: http://iron.metalloinvest.com/page/clientfocus $/ \% 20 \% \mathrm{D} 1 \% 84 \% \mathrm{D} 0 \% \mathrm{BE} \% \mathrm{D} 1 \% 82 \% \mathrm{D} 0 \% \mathrm{BE} \% 20 \% \mathrm{D} 0 \% \mathrm{~B} 2 \% 20 \% \mathrm{D} 1 \% 82 \% \mathrm{D} 0 \% \mathrm{~B} 5 \% \mathrm{D} 0 \% \mathrm{BB}$

14. Saxe, R., Weitz, B. (1982). The SOCO scale: A measure of the customer orientation of salespeople. Journal of Marketing Research, № 19 (3), 343-351 [in English].

15. Peters, T., Waterman, R. (1982). In Search of Excellence. Warner: New York, [in English].

16. Kohli, A., Jaworski, B. (1990). Market orientation: The construct, research propositions, and managerial implications. Journal of Marketing, № 54 (2), 1-18 [in English].

17. Deshpande, R., Farley, J. U. and Webster, F. E. (1993). Corporate culture, customer orientation and innovativeness in Japanese firms: a quadrant analysis. Journal of Marketing, № 57 (1), 23-37 [in English].

18. Ryzhkovskij, B. (2005). Kogda klient golosuet den'gami? [When does a customer vote in cash?], Upravlenie kompaniej, № 7, available at: http://www.advertology.ru/ article27313.htm [in Russian].

19. Harskij, K. (2007). Klientoorientirovannost' kak ona est' [Customer focus as it is], Upravlenie sbytom, № 3, 34 [in Russian].

20. Busarkina, V.V. (2007). Ponjatie klientoorientirovannosti predprijatija i problemy ee ocenki [The concept of customer orientation of the enterprise and the problems of its assessment], Problemy sovremennoj jekonomiki, № 4(24), available at: http://www.m-economy.ru/ art.php?nArtId=1660 [in Russian].

21. Mann, I. (2013). Klientoorientirovannost': chto delat', kak delat', vzjat' i sdelat' [Customer focus: what to do, how to do, take and do], Strategii, available at: http://pharma.net.ua/publications/articles/44566klientoorientirovannost-chto-delat-kak-delat-vzyat-i-sdelat [in Russian].

22. Strij, L.O. (2011). Marketynghove upravlinnja na rubezhi KhKhI stolittja: systemne doslidzhennja: monoghrafija [Marketing Management at the Turn of the 21st Century: A Systematic Study: A Monograph], Odesa, Astroprynt, 304 [in Ukrainian].

23. Kulinich, A. (2020). Klientoorientirovannost': vsja pravda ot praktichnogo teoretika [Customer focus: the whole truth from a practical theorist], Cifrovye strategii, available at: $\underline{\text { https://kulinich.ru/pravda-o- }}$ $\underline{\text { klientoorientirovannosti/ }}$ 